The International Journal of Digital Accounting Research

Vol. 8, N. 14, 2008, pp. 45-79

ISSN: $1577-8517$

\title{
A Comparison of the Information Technology Knowledge of United States and German Auditors
}

Marilyn Greenstein-Prosch. Arizona State University. Marilyn.Prosch@asu.edu

Thomas E. McKee. Medical University of South Carolina. temckee@ musc.edu

Reiner Quick, Darmstadt University of Technology. quick@ bwl.tu-darmstadt.de

\begin{abstract}
The International Federation of Accountants has stated that competence in information technology is imperative for the professional accountant due to its pervasive use in the business world. Auditors would normally be expected to have higher knowledge than the average accountant since they must audit the work of many different clients with diverse information systems. We surveyed 2,500 United States and German auditing professionals to determine their self-reported knowledge levels (IT self-efficacy) of 36 information technologies, some of which include various emerging technologies. Responses totaled 587 for a $23.5 \%$ overall response rate. A factor analysis of the 36 individual technologies revealed five underlying general constructs. Response statistics indicated both countries lacked significant knowledge for three of these five constructs.

Scores were then culturally standardized to appropriately compare United States and German responses. German auditors had significantly higher knowledge for the construct of networking and data transfer. U.S. auditors had significantly higher knowledge for three constructs: ecommerce technologies, general office automation, and audit automation technologies. No differences were found for the construct of accounting firm office automation technologies. This study provides a foundation and methodology by which future researchers can measure whether, as an "emerging technology" matures, greater convergence will occur over time across cultures in factor analysis, as in the case of the more mature construct, general office automations.
\end{abstract}

Submitted November 2007

Accepted July 2008

DOI: $10.4192 / 1577-8517-v 8 \_3$ 
Key words: information technology knowledge, auditing, audit practice, information technology definitions, auditing education.

\section{INTRODUCTION}

The International Federation of Accountants Education Committee has stated, "Information technology [IT] is pervasive in business, requiring the professional accountant to be competent in this technology" (IFAC 2006b, p. 5). Further, technology will continue to have a "dramatic impact on virtually every phase of the audit process" Bierstaker, et al (2001). Chang and Hwang (2003) comment on whether professional accountants are properly trained in IT, "given the dynamic nature of IT and its widespread adoption in business organizations, many in the accounting profession have voiced concerns over whether college education and professional training effectively and efficiently prepare accountants to meet these challenges." The accounting profession performs many roles where IT is used. Certainly in light of large scale business failures such as Enron, MCI-WorldCom, Parmalat, Comroad, etc., one of the most critical roles is auditing. Janvrin, et al. (2008) examine the use of audit IT and the perceived importance of IT use.

IT knowledge requirements for independent auditors are higher than for the average accountant since they typically serve a wide variety of clients with diverse information systems. The International Education Standard 8 (IFAC, 2006a) states that the knowledge content within the education and development program for audit professionals should include IT. The knowledge content of the IT subject area should include the following:

- IT systems for financial accounting and reporting, including relevant current issues and developments, and

- Frameworks for evaluating controls and assessing risks in accounting and reporting systems as appropriate for the audit of historical financial information.

Lymer and Debreceny (2003) discuss issues that have developed as auditors have moved towards trying to provide assurance on corporate reporting via the Internet. They find gaps between technology utilization and professional responses, leading to the conclusion that, "...the actual pronouncements made thus far by the various bodies around the world fall considerably short as a response to the challenges that arise from current and future Internet reporting technologies." This 
suggests that the international audit profession is having a problem adjusting to the rapidly changing technology landscape. "From computer-generated audit programs to audit software capable of testing the entire population of the client's data, technology is essential for accountants to understand the client's business processes and contend with the paperless audit environment" (Bierstaker, et al, 2001). The profession can benefit by identifying key technologies and conducting selfassessment to learn how knowledgeable its members are about these technologies. Toward that end, we identify 36 key technologies and survey the self-perceived IT knowledge level (IT self-efficacy) of U.S. and German auditors.

\section{THEORY AND HYPOTHESES FORMULATION}

According the technology acceptance model (TAM), a user's perception of their computer knowledge (self-efficacy) increases their perceptions of ease of use of the technology and system usefulness, which in turn, can affect their behavioral intentions (Davis 1989). Thus, examining auditor's perceptions of their IT skill levels should provide some insight into which technologies may be more likely to be viewed as useful and easy to use. Because of experience, users should have a greater comfort level with and knowledge of (self-efficacy) older, more mature technologies than with newer, emerging technologies.

We examine IT self-efficacy in two judgmentally selected countries. The U.S. was selected because of the size of its economy and highly developed audit profession. Germany was selected for a comparison because it is a continental European country with a large economy and highly developed audit profession. As the world's third strongest national economy, Germany holds a leading position in terms of its total economic output. Germany has the highest gross domestic product and the largest number of inhabitants in the European Union. In global trading of goods and services, Germany is in second place after the U.S. Further, Germany is a good comparison country for the U.S. since it has been touted as a leader in IT security surrounding data protection and for moving the center of gravity away from Silicon Valley to places like Walldorf, Germany where SAP began (The Economist, 2003). Financial statements audited by German auditors are relevant for U.S. investors because of the listing of major German companies at the NYSE, but also due to subsidiaries of U.S. companies in Germany. Moreover, German companies are often customers or suppliers of U.S. companies. 
As businesses increasingly become global, the necessity of cross-border audit teams is also increasing. Thus, an assessment of the skill levels of people in similar job positions, such as the auditors in this case, is important for global quality control. Germany, because of its comparability in terms of economics to the U.S., provides a good population of auditors for comparison to the U.S. Because of these similarities, we would expect that they would have relatively similar auditing skill levels.

Further, the primary function of external audits is to increase trust in financial statements. This function can only be fulfilled if an adequate audit quality is provided. Audit quality depends on an auditor's ability to detect errors (expertise) and auditor's willingness to report such errors (independence) (DeAngelo, 1981). In the current information age, IT knowledge is a very important element of auditor's expertise. If German auditors have less IT knowledge, then this may result in provision of lower audit quality, and ultimately lead to a lower level of trust by U.S. stakeholders in German financial statements (and vice versa, of course). Also, if auditors have lower IT self-efficacy, this may impact their perceived usefulness of emerging technologies, and lower the intention to adopt the technology. Thus, the main purpose of this paper is to reveal whether differences exist concerning the IT-related expertise (IT self-efficacy) between U.S. and German auditors. We propose the following hypotheses regarding the IT knowledge levels of auditors:

- H1: The perceived knowledge level (IT self-efficacy) of German and US auditing practitioners includes relevant, current information technologies.

- H2: German and US auditing practitioners have the same perceived knowledge (IT self-efficacy) of relevant, current information technologies.

This is an exploratory study, as we know of no other study that compares relative IT self-efficacy of auditors from different countries. As technology brings the world closer together, audit firms are faced with increasing their global reach. As such, understanding similarities and differences in the IT skill levels in various countries should be of interest to both the academic and practitioner communities. Since this study is exploratory, we do not have preconceptions regarding the relative skill levels. We have mentioned some of these reasons why we would expect similarities between the two groups, however, differences in the education 
systems do exist between auditors that study in the U.S. and those that study in Germany. The education system in Germany is more research-oriented than in the US and less emphasis is placed on preparation of the students for practice, and this may impact their relative skill levels.

First, however, an important question must be addressed - what are relevant, current information technologies? This paper reports the results of a literature search to identify significant audit technologies. It also reports on the results of 2,500 questionnaire surveys of auditor knowledge in the United States and Germany about the specific technologies uncovered in the literature search. The results should provide evidence whether to support the research hypotheses as well as provide individual auditors with a benchmark for examining their own knowledge levels.

\section{Information Technologies}

The IFAC defines information technology [IT] as:

"...hardware and software products, information system operations and management processes, IT controls frameworks, and the human resources and skills required to develop, use and control these products and processes to generate the required information." (IFAC, 2006b, p. 5)

This is a rather broad based definition since it includes "human resources and skills" in addition to hardware and software products. The current study narrows this slightly by focusing on hardware and software products. "Because of the dynamic nature and broad spectrum of IT, assembling a complete list of IT topics that are important to accounting professionals is very difficult" (Chang and Hwang, 2003). We initially began with the 25 information technologies which were included in a survey of the Norwegian auditing profession (McKee, 2000) since we wanted our research to build on prior research. A subsequent literature search which included IFAC publications, AICPA publications, a variety of journal articles, and an electronic commerce book added 11 additional technologies for the U.S. and German surveys. These 36 technologies are listed and briefly defined in Table 1-Information Technology Definitions. The original sources from which we identified the technologies are also listed in Table 1.

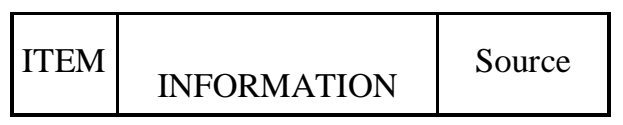




\begin{tabular}{|c|c|c|c|}
\hline & TECHNOLOGY & & \\
\hline 1 & Word Processing & IFAC 11 & $\begin{array}{l}\text { computer program that facilitates entry and preparation of documents } \\
\text { such as letters or reports. }\end{array}$ \\
\hline 2 & $\begin{array}{c}\text { Electronic } \\
\text { Spreadsheets }\end{array}$ & IFAC 11 & $\begin{array}{l}\text { software which allows the auditor to enter either alphanumeric or } \\
\text { numeric data and manipulate it either via standard functions or auditor } \\
\text { programmed functions }\end{array}$ \\
\hline 3 & E-Mail & IFAC 11 & exchange of mail messages via Intranets and/or the Internet. \\
\hline 4 & $\begin{array}{l}\text { Electronic Working } \\
\text { Papers }\end{array}$ & IFAC 11 & $\begin{array}{l}\text { software which generates a trial balance, lead schedules, and other } \\
\text { schedules useful for the recording of evidence in an audit or assurance } \\
\text { engagement }\end{array}$ \\
\hline 5 & $\begin{array}{l}\text { Internet Search \& } \\
\text { Retrieval }\end{array}$ & AICPA '94 & $\begin{array}{l}\text { permits user to search text that is in electronic format and retrieve, } \\
\text { view, and print desired text. }\end{array}$ \\
\hline 6 & Image Processing & $\begin{array}{l}\text { Helms \& } \\
\text { Mancino } \\
\quad 97\end{array}$ & $\begin{array}{l}\text { conversion of paper documents into electronic form through scanning } \\
\text { and the subsequent storage and retrieval of the electronic image }\end{array}$ \\
\hline 7 & $\begin{array}{c}\text { Electronic } \\
\text { Presentations }\end{array}$ & IFAC 11 & $\begin{array}{l}\text { software that facilitates the organization and use of text, voice, and/or } \\
\text { images to communicate concepts }\end{array}$ \\
\hline 8 & $\begin{array}{l}\text { Generalized Audit } \\
\text { Software }\end{array}$ & IFAC 11 & $\begin{array}{l}\text { computer program which helps the auditor access client computer data } \\
\text { files, extract relevant data, and perform some audit function such as } \\
\text { addition or comparison. }\end{array}$ \\
\hline 9 & Expert Systems & IFAC 11 & $\begin{array}{l}\text { computer software that provides relevant information and/or decision } \\
\text { models to assist a human in making a decision or accomplishing some } \\
\text { task. }\end{array}$ \\
\hline 10 & $\begin{array}{l}\text { Embedded Audit } \\
\text { Modules }\end{array}$ & AICPA '94 & programmed routines incorporated into an application program which \\
\hline 11 & $\begin{array}{l}\text { Real-time Audit } \\
\text { Modules }\end{array}$ & & are designed to perform an audit function \\
\hline 12 & $\begin{array}{l}\text { Database Search \& } \\
\text { Retrieval }\end{array}$ & IFAC 11 & $\begin{array}{l}\text { software that uses relational structures between data files and facilitates } \\
\text { varying data retrieval and use. }\end{array}$ \\
\hline 13 & Simulation Software & Elliott'94 & $\begin{array}{l}\text { abstraction of some aspect of real system via software. Auditor may } \\
\text { use model to evaluate the reliability of information from real world } \\
\text { sources. This may be thought of as a very high level analytical review } \\
\text { of a company's data. }\end{array}$ \\
\hline 14 & $\begin{array}{l}\text { Flowcharting/Data } \\
\text { Modeling }\end{array}$ & AICPA '94 & $\begin{array}{l}\text { software using the source code version of programs to produce } \\
\text { flowcharts of program logic }\end{array}$ \\
\hline 15 & $\begin{array}{c}\text { Computer Aided } \\
\text { Systems Engineering } \\
\text { Tools }\end{array}$ & IFAC 11 & $\begin{array}{l}\text { integrated package of computer tools that automate important aspects } \\
\text { of the software development process to increase software development } \\
\text { effectiveness in terms of productivity of systems development and } \\
\text { quality of developed systems. }\end{array}$ \\
\hline 16 & Encryption Software & $\begin{array}{l}\text { Helms \& } \\
\text { Mancino } \\
\quad 97\end{array}$ & $\begin{array}{l}\text { changing data using some type of encoding/decoding algorithm so that } \\
\text { unauthorized persons who can access the encrypted data will not be } \\
\text { able to read it or use it. }\end{array}$ \\
\hline 17 & Groupware & $\begin{array}{l}\text { Glover \& } \\
\text { Romney } \\
\text { '97 }\end{array}$ & $\begin{array}{l}\text { software that permits auditors to categorize, store, and share data } \\
\text { among themselves as well as communicate with each other about that } \\
\text { data, preferably in a real-time mode. }\end{array}$ \\
\hline
\end{tabular}




\begin{tabular}{|c|c|c|c|}
\hline 18 & $\begin{array}{l}\text { Cooperative } \\
\text { Client/Server } \\
\text { Environment }\end{array}$ & $\begin{array}{l}\text { Helms \& } \\
\text { Mancino } \\
\quad 97\end{array}$ & $\begin{array}{l}\text { distribution of processing functions between two or more computers as } \\
\text { in a local area network. This also includes end-user computing where } \\
\text { users on the network also process and store data on their personal } \\
\text { computers. }\end{array}$ \\
\hline 19 & Workflow Technology & $\begin{array}{c}\text { AICPA Top } \\
10 ` 97\end{array}$ & $\begin{array}{l}\text { software and hardware that facilitates the capture of data in the work } \\
\text { place to improve management of the business. For example, using an } \\
\text { electronic scanner to record the movement of materials in a warehouse } \\
\text { based on the barcodes on the materials. }\end{array}$ \\
\hline 20 & $\begin{array}{l}\text { Database Design \& } \\
\text { Installation }\end{array}$ & IFAC 11 & $\begin{array}{l}\text { software that permits the creation and use of relational structures } \\
\text { between data files }\end{array}$ \\
\hline 21 & $\begin{array}{l}\text { Time Management \& } \\
\text { Billing Systems }\end{array}$ & IFAC 11 & $\begin{array}{l}\text { computer program which assists in capturing, managing, billing, and } \\
\text { reporting time spent on professional activities. }\end{array}$ \\
\hline 22 & Test Data & IFAC 11 & $\begin{array}{l}\text { a set of transactions processed by the auditor to test the programmed or } \\
\text { procedural operations of a computer application }\end{array}$ \\
\hline 23 & $\begin{array}{c}\text { Small Business } \\
\text { Accounting Software }\end{array}$ & IFAC 11 & $\begin{array}{l}\text { accounting software package used to record transactions, maintain } \\
\text { general and subsidiary ledgers, and generate financial statements. }\end{array}$ \\
\hline 24 & $\begin{array}{c}\text { Digital } \\
\text { Communications }\end{array}$ & $\begin{array}{c}\text { AICPA Top } \\
102000\end{array}$ & $\begin{array}{l}\text { bandwidth - telecommunications devices used to facilitate the rapid } \\
\text { and unfettered transfer of data. }\end{array}$ \\
\hline 25 & $\begin{array}{c}\text { Tax Return } \\
\text { Preparation Software }\end{array}$ & IFAC 11 & $\begin{array}{l}\text { software, perhaps incorporating expert knowledge, which assists the } \\
\text { accountant/auditor in identifying relevant information, capturing and } \\
\text { recording it in a manner that can be filed with tax authorities. }\end{array}$ \\
\hline 26 & $\begin{array}{c}\text { Firewall } \\
\text { Software/Hardware }\end{array}$ & $\begin{array}{c}\text { AICPA Top } \\
102000\end{array}$ & $\begin{array}{l}\text { Part of "security technology" that enforces an access control policy } \\
\text { between two networks. }\end{array}$ \\
\hline 27 & $\begin{array}{l}\text { User Authentication } \\
\text { Systems }\end{array}$ & $\begin{array}{c}\text { AICPA Top } \\
102000\end{array}$ & devices used to verify that a system user is who he/she claims to be. \\
\hline 28 & EDI-Traditional & IFAC 11 & $\begin{array}{l}\text { transfer of data or payments electronically between computers using } \\
\text { software that may, or may not, require human intervention to affect the } \\
\text { transfer. }\end{array}$ \\
\hline 29 & EDI-Web Based & $\begin{array}{l}\text { Greenstein } \\
\& \text { Feinman, } \\
2000\end{array}$ & The extension to XML-based EDI \\
\hline 30 & $\begin{array}{c}\text { Wireless } \\
\text { Communications }\end{array}$ & \begin{tabular}{|c|} 
AICPA Top \\
102000
\end{tabular} & $\begin{array}{l}\text { the ability to transfer digital data without the use of cables, twisted- } \\
\text { pair, or fiber optics. }\end{array}$ \\
\hline 31 & Agent Technologies & \begin{tabular}{|c|} 
AICPA Top \\
102000
\end{tabular} & $\begin{array}{l}\text { programmed modules that are given certain levels of authority and } \\
\text { autonomy to act on behalf of their "supervisor", such as to decide } \\
\text { whether to order more inventory and from which supplier }\end{array}$ \\
\hline 32 & $\begin{array}{l}\text { Intrusion Detection \& } \\
\text { Monitoring }\end{array}$ & $\begin{array}{l}\text { AICPA Top } \\
102000 \text { \& } \\
\text { Greenstein } \\
\& \text { Feinman }\end{array}$ & $\begin{array}{l}\text { Part of "security technology" that identifies unauthorized requests for } \\
\text { services }\end{array}$ \\
\hline 33 & $\begin{array}{c}\text { Internal Network } \\
\text { Configurations }\end{array}$ & IFAC 11 & $\begin{array}{l}\text { linkage of individuals and data through hardware and software systems } \\
\text { that permit the exchange of various types of data. }\end{array}$ \\
\hline 34 & $\begin{array}{l}\text { External Network } \\
\text { Configurations }\end{array}$ & $\begin{array}{c}\text { AICPA Top } \\
102000\end{array}$ & $\begin{array}{l}\text {-intranet, extranet, and Internet access devices than enable users } \\
\text { physically separated from the server to access it. }\end{array}$ \\
\hline 35 & $\begin{array}{l}\text { Enterprise Resource } \\
\text { Planning }\end{array}$ & $\begin{array}{c}\text { McKee } \\
2000\end{array}$ & business-wide information systems that cross boundaries \\
\hline
\end{tabular}




\begin{tabular}{|c|c|c|l|}
\hline 36 & $\begin{array}{c}\text { Application Service } \\
\text { Providers }\end{array}$ & $\begin{array}{c}\text { McKee } \\
2000\end{array}$ & $\begin{array}{l}\text { Companies which host (provide hardware, software and connectivity) } \\
\text { for specific business applications }\end{array}$ \\
\hline
\end{tabular}

Table 1. Information Technology Definitions ${ }^{1}$

The technologies are not necessarily completely distinct from each other since many of them are based on similar information technology fundamentals or capabilities. For example, electronic spreadsheets may have data import/export capabilities and statistical analysis capabilities as do generalized audit software. Nevertheless, we believe that the technologies are distinct enough that audit professionals should be knowledgeable about each of them. Because of the rapidly changing and somewhat open ended nature of information technology, there could be other significant technologies which were not included in this survey.

\section{Related Norwegian Prior Study}

McKee (2000) conducted an information technology knowledge survey of the Norwegian practicing auditing profession during late 1998 and early 1999. The survey encompassed 25 information technologies. Major findings from this survey were:

- A large number of professionals indicated either no knowledge or relatively low levels of knowledge for the 25 information technologies surveyed.

- Female respondents rated their individual and overall knowledge lower than male respondents.

- $71 \%$ of the respondents believed they had received less than adequate coverage of information technologies in their college or university careers.

- $17.3 \%$ of the respondents self-rated their overall knowledge of information technology as either low or very low.

- "Big 5" audit firm respondents self-rated their overall knowledge of information technology higher than did other respondents [statistically significant at .05 level] in 20 of the 25 technologies surveyed.

\footnotetext{
${ }^{1}$ This table is taken from M. Greenstein and T.E. McKee, “Assurance Practitioners' and Educators' Self-Perceived IT Knowledge Level: An Empirical Assessment," International Journal of Accounting Information Systems, Vo. 5 (2004), 213-243.
} 


\section{METHODOLOGY}

As previously noted, this study built on the McKee 2000 Norwegian information technology study. Eleven additional technologies were added to the Norwegian information technology survey instrument. This expanded survey containing 36 information technologies was then pre-tested and modified. The overall design of the research is illustrated in Figure 1.

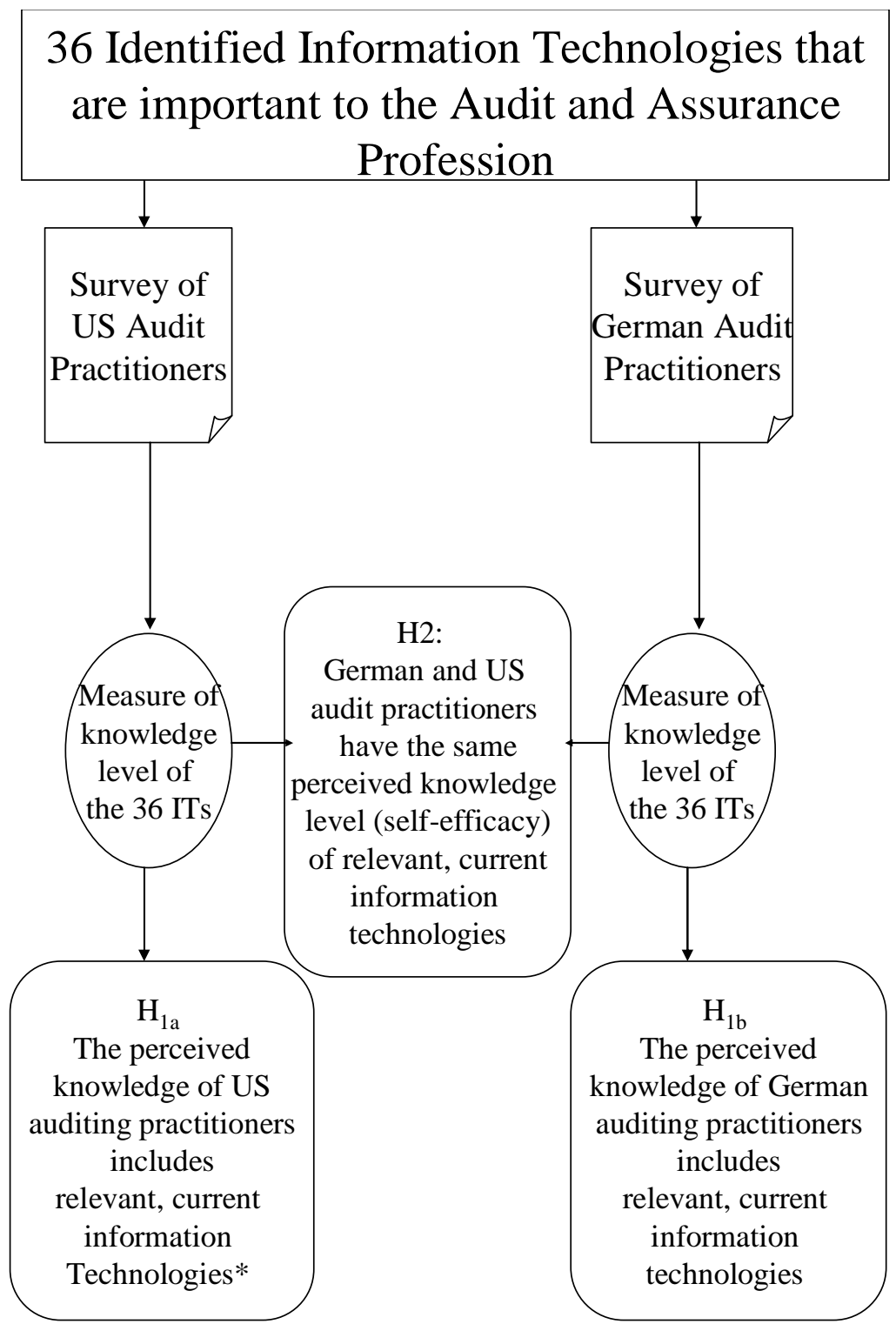

*Previously examined by Greenstein \& McKee [2004]

Figure 1.Research Designs 
The survey instrument measures self-assessment of IT knowledge level. Self assessment of the technical knowledge of auditors is certainly not new (Kennedy and Peecher, 1997). In most cases, the research conducted in the psychology field indicates that individuals' likelihood assessments of their own knowledge are overconfident (Keren, 1991). These indications of overconfidence by auditors in self-assessments are generally supported (Solomon, et al, 1985; Moeckel and Plumlee, 1989; Moeckel, 1990; Kennedy and Peecher, 1997). Thus, the tradition of assessing self-assessed knowledge exists in the literature, but we will be conservative in our analysis of the results, realizing that respondents are likely to over-estimate their own knowledge base.

The expanded survey of 36 information technologies, in English, was then mailed to 1,000 accounting information systems and auditing professors and 1,000 audit practitioners in the United States during the first half of 2000 (Greenstein and McKee, 2004). Only the survey responses from the audit practitioners are included in this article. A German language survey, similar to the expanded survey used in the United States, was distributed in Germany during 2000-2001 to 1500 German professional auditors (McKee and Quick, 2003). This survey was not completely random as, after inspection of the randomly selected addresses, it was discovered that only one address was present for each office of the "Big 5" Audit firms. Thus, Big 5 auditors were underrepresented in the initial sample. As a result, one of the Big 5 audit firms was requested to distribute surveys internally. This resulted in $42 \%$ of the responses being from "Big 5" firms and 47\% from "non-Big 5" firms with $11 \%$ not indicating a firm affiliation.

Surveys distributed to audit practitioners in the two countries totaled 2,500. There were 587 usable responses for a $23.5 \%$ overall response rate. Table 2-Survey Response Rates shows the various response rates for the two surveys. The survey results should be reasonably representative of the auditing professions in the two countries surveyed.

\begin{tabular}{|l|l|l|l|}
\hline & United States & Germany & Total \\
\hline Surveys Distributed & 1,000 & 1,500 & 2,500 \\
\hline Completed Responses & 246 & 341 & 587 \\
\hline Response Rate & $24.6 \%$ & $23.0 \%$ & $23.5 \%$ \\
\hline
\end{tabular}

Table 2. Survey Response Rates 


\section{Demographic Response Data}

Demographic data on the audit practitioners included in this survey is presented in Table 3-Demographic Data On Respondents. This data indicates that respondents represented a wide variety of ages, experience levels, and position levels.

\begin{tabular}{|c|c|c|c|}
\hline & $\begin{array}{l}\text { United } \\
\text { States }\end{array}$ & Germany & Overall \\
\hline \multicolumn{4}{|l|}{ Gender } \\
\hline Male & $59.4 \%$ & $88.8 \%$ & $70.7 \%$ \\
\hline Female & $39.0 \%$ & $9.4 \%$ & $27.7 \%$ \\
\hline Missing & $1.6 \%$ & $1.8 \%$ & $1.6 \%$ \\
\hline \multicolumn{4}{|l|}{ Age In Years } \\
\hline Minimum & 23 & 24 & 23 \\
\hline Average & 42 & 43.4 & 42.5 \\
\hline Maximum & 72 & 71 & 72 \\
\hline Median & 41 & 44 & \\
\hline \multicolumn{4}{|l|}{ Experience In Years } \\
\hline Minimum & 0 & 1 & 0 \\
\hline Average & 12 & 17.6 & 14.2 \\
\hline Maximum & 37 & 45 & 45 \\
\hline Median & 15 & 17 & \\
\hline \multicolumn{4}{|l|}{ Current Position $^{2}$} \\
\hline Staff/Assistant & $6 \%$ & $4 \%$ & $5 \%$ \\
\hline Senior/Supervisor & $16 \%$ & $7 \%$ & $13 \%$ \\
\hline Manager & $23 \%$ & $25 \%$ & $24 \%$ \\
\hline Partner & $50 \%$ & $58 \%$ & $53 \%$ \\
\hline Other & $4 \%$ & $6 \%$ & $5 \%$ \\
\hline Missing & $1 \%$ & $0 \%$ & $0 \%$ \\
\hline
\end{tabular}

Table 3. Demographic Data on Respondents

Female respondents comprised $39 \%$ of the U.S. responses as compared to only 9\% in Germany. The German result is consistent with the fact that females currently comprise approximately $12.3 \%$ of Wirtschaftsprüfer and $13.8 \%$ of vereidigter Buchprüfer (the two categories of German auditors). We also note that the experience level of the German respondents averaged 18 years as compared to

\footnotetext{
${ }^{2}$ U.S. data is only for 103 respondents who indicated that they performed traditional audits.
} 
only 12 years for the U.S. respondents, and the average position of German participants is higher. This suggests that, on average, the German respondents were more likely to be more highly experienced males than the U.S. respondents.

\section{Response Variable Correlations}

The questionnaire which respondents received asked them to rank their knowledge of the 36 information technologies on a 7 point scale anchored with terms as follows:

No Knowledge

Expert Knowledge

$\begin{array}{lllllll}1 & 2 & 3 & 4 & 5 & 6 & 7\end{array}$

Table 4-Information Technology Knowledge of Audit Practitioners shows the mean, standard deviation, and median of the actual U.S. and German auditor responses to the 36 information technology questions.

U.S.

Unadj. Std.

$\begin{aligned} \text { Item } & \text { Information Technology } \\ 1 & \text { Word Processing } \\ 2 & \text { Electronic Spreadsheets } \\ 3 & \text { E-Mail } \\ 4 & \text { Electronic Working Papers } \\ 5 & \text { Internet Search \& Retrieval } \\ 6 & \text { Image Processing } \\ 7 & \text { Electronic Presentations } \\ 8 & \text { Generalized Audit Software } \\ 9 & \text { Expert Systems } \\ 10 & \text { Embedded Audit Modules } \\ 11 & \text { Real-time Audit Modules } \\ 12 & \text { Database Search \& Retrieval } \\ 13 & \text { Simulation Software } \\ 14 & \text { Flowcharting/Data Modeling } \\ 15 & \text { CASE Tools } \\ 16 & \text { Encryption Software } \\ 17 & \text { Groupware } \\ 18 & \text { Cooperative Client/Server Environment } \\ 19 & \text { Workflow Technology }\end{aligned}$

Mean Dev.

$4.99 \quad 1.18$

$\begin{array}{lll}5.38 & 1.20 & 6\end{array}$

$\begin{array}{lll}5.09 & 1.17 & 5\end{array}$

$\begin{array}{lll}3.70 & 1.73 \quad 4\end{array}$

$\begin{array}{lll}4.78 & 1.32 & 5\end{array}$

$\begin{array}{lll}2.86 & 1.60 & 3\end{array}$

$\begin{array}{lll}3.38 & 1.77 \quad 3\end{array}$

$\begin{array}{lll}2.94 & 1.68 & 3\end{array}$

$\begin{array}{lll}2.00 & 1.35 & 1\end{array}$

$\begin{array}{lll}2.08 & 1.42 & 1\end{array}$

$\begin{array}{lll}2.10 & 1.42 & 1\end{array}$

$\begin{array}{lll}3.51 & 1.59 & 3\end{array}$

$\begin{array}{lll}2.64 & 1.54 & 2\end{array}$

$\begin{array}{lll}2.94 & 1.60 & 3\end{array}$

$\begin{array}{lll}1.66 & 1.08 & 1\end{array}$

$\begin{array}{lll}1.59 & 1.06 & 1\end{array}$

$\begin{array}{lll}2.80 & 1.71 & 3\end{array}$

$\begin{array}{lll}2.73 & 1.65 & 2\end{array}$

$\begin{array}{lll}1.96 & 1.28 & 1\end{array}$

\section{Germany}

Unadj. Std.

Mean Dev. Median

$\begin{array}{lll}4.61 & 1.19 & 5\end{array}$

$\begin{array}{lll}4.72 & 1.30 & 5\end{array}$

$\begin{array}{lll}4.34 & 1.30 & 4\end{array}$

$\begin{array}{lll}2.83 & 1.66 & 3\end{array}$

$\begin{array}{lll}3.86 & 1.41 & 4\end{array}$

$\begin{array}{lll}2.69 & 1.41 & 2\end{array}$

$\begin{array}{lll}3.30 & 1.67 & 3\end{array}$

$\begin{array}{lll}2.76 & 1.59 & 2\end{array}$

$\begin{array}{lll}1.95 & 1.35 & 1\end{array}$

$\begin{array}{lll}1.95 & 1.38 & 1\end{array}$

$\begin{array}{lll}1.64 & 1.09 & 1\end{array}$

$\begin{array}{lll}3.05 & 1.57 & 3\end{array}$

$\begin{array}{lll}2.05 & 1.35 & 1\end{array}$

$\begin{array}{lll}2.40 & 1.48 \quad 2\end{array}$

$\begin{array}{lll}1.51 & 1.01 & 1\end{array}$

$\begin{array}{lll}1.72 & 1.16 & 1\end{array}$

$\begin{array}{lll}2.50 & 1.67 & 2\end{array}$

$\begin{array}{lll}1.98 & 1.41 & 1\end{array}$

$\begin{array}{lll}1.50 & .97 & 1\end{array}$




$\begin{array}{llcccccc}20 & \text { Database Design \& Installation } & 2.48 & 1.52 & 2 & 1.95 & 1.30 & 1 \\ 21 & \text { Time Management \& Billing Systems } & 3.67 & 1.77 & 4 & 3.22 & 1.57 & 3 \\ 22 & \text { Test Data } & 2.67 & 1.69 & 2 & 1.74 & 1.26 & 1 \\ 23 & \text { Small Business Accounting Software } & 4.52 & 1.72 & 5 & 4.58 & 1.86 & 5 \\ 24 & \text { Digital Communications } & 1.89 & 1.28 & 1 & 2.81 & 1.65 & 2 \\ 25 & \text { Tax Return Preparation Software } & 4.83 & 1.84 & 5 & 4.73 & 1.99 & 5 \\ 26 & \text { Firewall Software/Hardware } & 1.85 & 1.25 & 1 & 1.96 & 1.32 & 1 \\ 27 & \text { User Authentication Systems } & 1.77 & 1.27 & 1 & 2.02 & 1.32 & 2 \\ 28 & \text { EDI-Traditional } & 2.24 & 1.47 & 2 & 3.20 & 1.68 & 3 \\ 29 & \text { EDI-Web Based } & 2.20 & 1.42 & 2 & 2.74 & 1.61 & 2 \\ 30 & \text { Wireless Communications } & 2.78 & 1.63 & 3 & 3.08 & 1.54 & 3 \\ 31 & \text { Agent Technologies } & 1.81 & 1.30 & 1 & 1.64 & 1.10 & 1 \\ 32 & \text { Intrusion Detection \& Monitoring } & 1.67 & 1.19 & 1 & 1.87 & 1.20 & 1 \\ 33 & \text { Internal Network Configurations } & 2.11 & 1.44 & 1 & 2.40 & .54 & 2 \\ 34 & \text { External Network Configurations } & 1.78 & 1.23 & 1 & 1.86 & 1.27 & 1 \\ 35 & \text { Enterprise Resource Planning } & 1.85 & 1.42 & 1 & 1.59 & 1.22 & 1 \\ 36 & \text { Application Service Providers } & 1.98 & 1.40 & 1 & 1.40 & .89 & 1\end{array}$

Table 4. Descriptive Statistics - Mean IT Knowledge Level - Raw Data Respondents ranked their own knowledge of 36 information technologies on a 1 to 7 scale where $1=$ No Knowledge and $7=$ Expert Knowledge.

In order to determine if the overall IT knowledge results for the U.S. versus the German groups were related we computed the Pearson correlation coefficient for the mean values of the 36 information technologies in the two groups. This correlation coefficient was .911 which has a two-tailed significance of .000 . This means that the overall IT knowledge results for the two groups are statistically significantly related.

Because cultural differences in response patterns to questionnaire scales may occur when an instrument is administered to subjects in different cultures, an adjustment was made to the data to culturally standardize scores (Leung and Bond, 1989 and Smith, Peterson \& Schwartz, 2002).

$\operatorname{SS}(i, j)=[S(i)-\mu(j)] / \sigma(j)$

where

- $\quad S S(i, j)=$ subject's score for item $i$ in culture $j$

- $\mu(j)=$ overall mean of all 36 item scores for culture $j$

- $\sigma(j)=$ overall std. dev. of item scores for culture $\mathrm{j}$ 
- US: $\mu(j)=2.7895$ and $\sigma(j)=1.141$

- Germany: $\mu(j)=2.6114$ and $\sigma(j)=1.0035$

Such standardization techniques are not without bias, however. According to Fischer (2004) "dealing with cross-cultural response patterns is arguably one of the most challenging issues in cross-cultural survey research." Smith (2004) illustrates that such adjustments might actually not reduce method biases, but instead communication styles and related cultural characteristics. Fischer (2004) points out that, according to these prior studies, that standardization could remove variation that is substantial and related to culture. Thus, in an effort to make sure that the analysis is robust to this cultural adjustment, we analyze and report any differences in results due to this transformation.

Because $\mathrm{H} 1$ does not compare the two populations (cultures) against one another, the raw data is used in that analysis. In examining $\mathrm{H} 2$, all analyses are conducted on both the raw data and culturally adjusted data, and any differences found are examined and discussed. Identifying such differences is important as evidence increasingly becomes available that "response bias might actually be a variable of substantive interest and a true indicator of cross-cultural differences" (Fischer 2004).

\section{Factor Analysis of the 36 Technology Skills}

As noted by Yu (2002) many IT technologies “....are interrelated and should not stand alone. For example, privacy, security, and mobile and wireless technologies are interrelated." Accordingly, we believed a factor analysis of the 36 specific technologies might reveal more about possible interrelationships and fundamental technology constructs. The 36 items listed in Table 1 were factor analyzed on the perceived skill level response for the 36 information technologies to determine the number and character of the underlying constructs.

Because the two groups of auditors may be inherently different, factor analysis is conducted on each of the populations to determine if pooled analysis of the groups is appropriate. The results of the factor analysis extraction for the raw data and the culturally adjusted data discussed in this section were $100 \%$ identical when run on the raw data and the culturally adjusted data. Considering the standard transformation made to the data and the techniques of factor analysis, this is to be 
expected, and would certainly be suspect if the results were not identical. As illustrated in Tables 5 and 6, the items loaded slightly differently for the two groups. Factor analysis using Varimax rotation is used, and responses for each of the two groups loaded into six factors, explaining $67 \%$ and $66 \%$ of the variance respectively, for the US and German auditors. The individual factors and underlying items, as well as the relative explanatory value of the items, vary somewhat between the two populations.

The bolded, underlined items in Tables 5 and 6 identify the items that clearly loaded on only one component. The rule used in this process was to choose items with a score of .50 or better. The items in italics indicate those items that did not meet this criteria. For the U.S. auditors, three items did not prominently load onto any component: simulation software, flowcharting/data modeling, and cooperative client/server environment. For the German auditors, four items did not meet this criteria: database search and retrieval, flowcharting/data modeling, groupware, and database design and installation.

\begin{tabular}{|c|c|c|c|c|c|c|}
\hline & \multicolumn{6}{|c|}{ Component / \% Variance Explained } \\
\hline & $\begin{array}{c}1 \\
(23.4 \%) \\
\end{array}$ & $\begin{array}{c}2 \\
(10.6 \%) \\
\end{array}$ & $\begin{array}{c}3 \\
(10.6 \%) \\
\end{array}$ & $\begin{array}{c}4 \\
(8.1 \%) \\
\end{array}$ & $\begin{array}{c}5 \\
(7.7 \%) \\
\end{array}$ & $\begin{array}{c}6 \\
(7.0 \%) \\
\end{array}$ \\
\hline Word Processing & .099 & $\underline{.814}$ & .057 & .144 & .042 & .133 \\
\hline Electronic Spreadsheets & -.006 & .674 & .075 & .291 & .046 & .190 \\
\hline E-Mail & .088 & $\underline{.821}$ & .191 & -.128 & .135 & -.002 \\
\hline Electronic Working Papers & .028 & .318 &.$\underline{557}$ & .173 & .091 & .203 \\
\hline Internet Search \& Retrieval & .221 & .712 & .175 & .086 & .050 & .145 \\
\hline Image Processing & .324 &.$\underline{517}$ & .336 & .100 & .093 & .020 \\
\hline Electronic Presentations & .211 &. .563 & .235 & .246 & .294 & -.219 \\
\hline Generalized Audit Software & .123 & .207 & .645 & -.088 & .078 & .321 \\
\hline Expert Systems & .337 & .118 & $\underline{.603}$ & .310 & .193 & -.018 \\
\hline Embedded Audit Modules & .220 & .184 & .802 & .172 & .154 & .070 \\
\hline Real-time Audit Modules & .277 & .155 & .798 & .206 & .183 & .061 \\
\hline Database Search \& Retrieval & .236 & .438 & .310 &.$\underline{588}$ & .085 & .075 \\
\hline Simulation Software & .334 & .173 & .426 & .488 & .120 & .206 \\
\hline Flowcharting/Data Modeling & .335 & .308 & .302 & .415 & .268 & .062 \\
\hline CASE Tools & .558 & .053 & .393 & .094 & .110 & .176 \\
\hline Encryption Software & .839 & .163 & .182 & .137 & .073 & .025 \\
\hline Groupware & .148 & .195 & .204 & .171 &.$\underline{602}$ & .037 \\
\hline $\begin{array}{l}\text { Coop. Client/Server } \\
\text { Environment }\end{array}$ & .427 & .209 & .061 & .445 & .359 & .125 \\
\hline
\end{tabular}




\begin{tabular}{|c|c|c|c|c|c|c|}
\hline Workflow Technology & $\underline{578}$ & .044 & .177 & .402 & .392 & .022 \\
\hline $\begin{array}{l}\text { Database Design \& } \\
\text { Installation }\end{array}$ & .400 & .210 & .145 &.$\underline{651}$ & .107 & .155 \\
\hline Time Mgt. \& Billing Systems & .188 & .171 & .188 & .331 & .283 &.$\underline{638}$ \\
\hline Test Data & .414 & .071 & .226 &.$\underline{529}$ & .184 & .242 \\
\hline $\begin{array}{l}\text { Small Bus. Accounting } \\
\text { Software }\end{array}$ & .108 & .115 & .122 & .184 & .052 &.$\underline{832}$ \\
\hline Digital Communications &.$\underline{749}$ & .163 & .053 & .204 & .175 & .153 \\
\hline $\begin{array}{l}\text { Tax Return Preparation } \\
\text { Software }\end{array}$ & .118 & .066 & .151 & -.025 & .018 &.$\underline{856}$ \\
\hline Firewall Software/Hardware & $\underline{.814}$ & .104 & .191 & .181 & .124 & .030 \\
\hline User Authentication Systems & $\underline{.832}$ & .096 & .114 & .226 & .107 & .063 \\
\hline EDI-Traditional &.$\underline{525}$ & .061 & .169 & .289 &.$\underline{639}$ & .121 \\
\hline EDI-Web Based* & $\underline{.576}$ & .139 & .160 & .220 & $\underline{.575}$ & .087 \\
\hline Wireless Communications & .455 & .158 & .155 & -.134 & $\underline{633}$ & .287 \\
\hline Agent Technologies &. & .047 & .284 & .129 & .415 & .104 \\
\hline $\begin{array}{l}\text { Intrusion Detection \& } \\
\text { Monitoring }\end{array}$ & $\underline{.823}$ & .104 & .267 & .082 & .110 & .066 \\
\hline $\begin{array}{l}\text { Internal Network } \\
\text { Configurations }\end{array}$ & .728 & .238 & -.012 & .117 & .058 & .224 \\
\hline $\begin{array}{l}\text { External Network } \\
\text { Configurations }\end{array}$ & $\underline{.862}$ & .138 & .099 & .085 & .214 & .100 \\
\hline Enterprise Resource Planning & .601 & .138 & .256 & .201 & .325 & -.102 \\
\hline Application Service Providers & $\underline{\mathbf{5 2 1}}$ & .009 & .237 & .357 & .356 & .014 \\
\hline
\end{tabular}

Table 5. U.S. Auditors- Rotated Component Matrix

Extraction Method: Principal Components. Rotation: Varimax with Kaiser Normalization. Factor loadings are $100 \%$ identical using both raw data and culturally adjusted data.

\begin{tabular}{|l|c|c|c|c|c|c|}
\hline & \multicolumn{6}{|c|}{ Component /\% of Variance Explained } \\
\hline & 1 & 2 & 3 & 4 & 5 & 6 \\
& $(18.4 \%)$ & $(14.0 \%)$ & $(12.2 \%)$ & $(11.7 \%)$ & $(6.8 \%)$ & $(3.3 \%)$ \\
\hline Word Processing & .187 & .111 & $\mathbf{. 8 1 6}$ & .004 & .276 & .134 \\
Electronic Spreadsheets & .170 & .047 & $\underline{\mathbf{. 1 4}}$ & .092 & .260 & .152 \\
E-Mail & .123 & .316 & $\underline{\mathbf{. 6 7 9}}$ & .133 & -.123 & .096 \\
Electronic Working Papers & .196 & .241 & .375 & .349 & -.165 & $\underline{\mathbf{. 6 0 6}}$ \\
Internet Search \& Retrieval & .120 & .337 & $\underline{\mathbf{. 6 7 0}}$ & .172 & -.051 & -.102 \\
Image Processing & .227 & .264 & $\underline{\mathbf{. 5 3 6}}$ & .391 & .013 & -.298 \\
Electronic Presentations & .191 & .143 & $\underline{\mathbf{. 6 3 4}}$ & .306 & -.338 & .024 \\
Generalized Audit Software & .249 & .169 & .280 & $\underline{\mathbf{. 5 8 5}}$ & .052 & .398 \\
Expert Systems & .248 & .098 & .015 & $\underline{\mathbf{. 7 3 0}}$ & .195 & .012 \\
Embedded Audit Modules & .253 & .183 & .185 & $\underline{\mathbf{. 7 1 6}}$ & .074 & .102 \\
Real-time Audit Modules & .401 & .092 & .122 & $\underline{\mathbf{. 6 9 8}}$ & .062 & .068
\end{tabular}




\begin{tabular}{|c|c|c|c|c|c|c|}
\hline Database Search \& Retrieval & .185 & .381 & .358 & .464 & .293 & -.266 \\
\hline Simulation Software & .333 & .255 & .199 &.$\underline{596}$ & .133 & -.118 \\
\hline Flowcharting/Data Modeling & .447 & .081 & .402 & .450 & -.041 & .051 \\
\hline CASE Tools & .730 & .152 & .181 & .259 & .049 & -.032 \\
\hline Encryption Software & $\underline{.600}$ & .275 & .253 & .239 & .037 & .081 \\
\hline Groupware & .231 & .336 & .393 & .380 & -.328 & .234 \\
\hline $\begin{array}{l}\text { Coop. Client/Server } \\
\text { Environment }\end{array}$ & $\underline{.508}$ & .488 & .233 & .302 & -.051 & -.105 \\
\hline Workflow Technology & $\underline{.681}$ & .175 & .150 & .405 & -.059 & -.044 \\
\hline Database Design \& Installation & .488 & .453 & .306 & .271 & .009 & -.327 \\
\hline Time Mgt. \& Billing Systems & .138 &.$\underline{548}$ & .096 & .335 & .226 & .107 \\
\hline Test Data &. & .373 & .240 & .183 & -.009 & -.076 \\
\hline Small Bus. Accounting Software & .135 & .214 & .014 & .145 & $\underline{.809}$ & -.070 \\
\hline Digital Communications & .219 & $\underline{.575}$ & .232 & .154 & .276 & -.115 \\
\hline Tax Return Preparation Software & .006 & .234 & .045 & .164 &.$\underline{838}$ & .013 \\
\hline Firewall Software/Hardware & .634 & $\underline{.510}$ & .133 & .059 & .237 & .054 \\
\hline User Authentication Systems & .621 & .385 & .093 & .041 & .317 & .158 \\
\hline EDI-Traditional & .302 & $\underline{656}$ & .260 & .116 & .225 & -.073 \\
\hline EDI-Web Based & .341 & .647 & .341 & .124 & .161 & -.121 \\
\hline Wireless Communications & .097 & .645 & .166 & .085 & .174 & .289 \\
\hline Agent Technologies & $\underline{.569}$ & .253 & .090 & .276 & .255 & .108 \\
\hline $\begin{array}{l}\text { Intrusion Detection \& } \\
\text { Monitoring }\end{array}$ &. & .423 & .107 & .190 & .212 & .137 \\
\hline Internal Network Configurations & .363 &.$\underline{671}$ & .131 & .167 & .031 & .065 \\
\hline $\begin{array}{l}\text { External Network } \\
\text { Configurations }\end{array}$ & .462 &.$\underline{639}$ & .104 & .109 & -.088 & .118 \\
\hline Enterprise Resource Planning & .735 & .096 & .154 & .288 & -.077 & -.013 \\
\hline Application Service Providers & .800 & .146 & .087 & .223 & -.015 & .061 \\
\hline
\end{tabular}

Table 6. German Auditors- Rotated Component Matrix

Extraction Method: Principal Components. Rotation: Varimax with Kaiser Normalization.

Factor loadings are $100 \%$ identical using both raw data and culturally adjusted data.

In order to compare the US and German audit skill levels, having consistent and comparable constructs is desirable. Also, identifying structural differences in the two cultures is interesting and important to future researchers. Towards that end, Venn diagrams are used to visually identify logical, common constructs across the two groups as illustrated in Figure 2. The underlined items from the factor loading statistics in Tables 5 and 6 are grouped according their U.S. and German Components and overlaps can be readily seen. Two items for the U.S. group, EDITraditional and EDI-Web-based had loading scores of .50 or better on two 
components, accordingly these items are illustrated in Figure 2 under both components with an asterisk. One item for the German group, firewall, has loading scores of .50 or better on two items, and these items are illustrated in Figure 2 under both components with two asterisks.

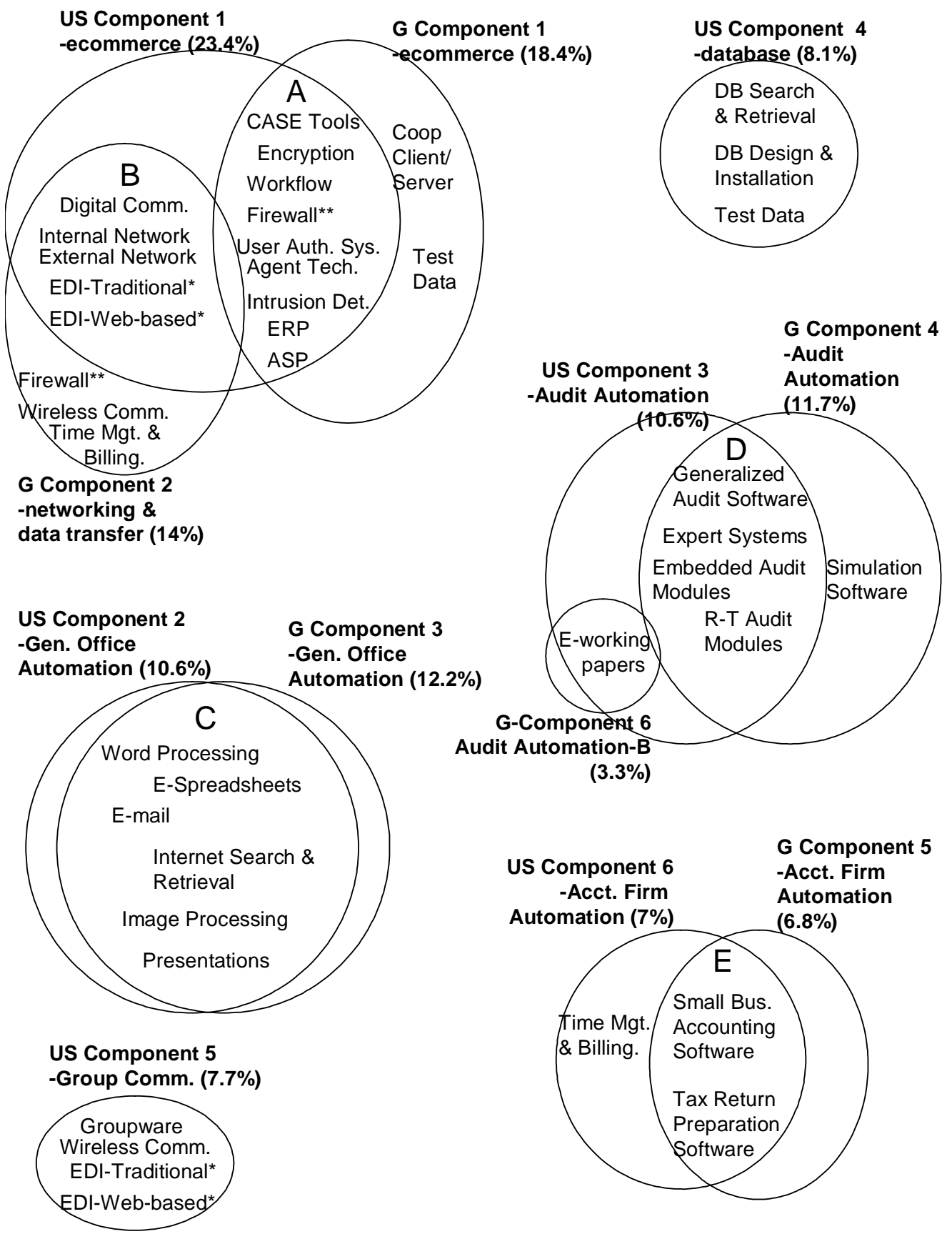

Figure 2. Component Comparison

* denotes items that load on two components for US auditors

** denotes item that loads on two components for $\mathrm{G}$ auditors 
By identifying commonalities using Figure 2 as a visual aid, five "pooled" constructs are identified as A,B,C,D,E. Item A is labeled as E-commerce and Advanced Technologies. Item B is a new construct, not previously identified as a single construct by Greenstein and McKee[2004]. Essentially, for the US population the factor analysis groups many more items into the "e-commerce" construct, but the factor analysis of the German population groups these items into two distinct constructs. So, for purpose of comparing the two populations, we duly note that the US had more homogeneity in their responses on these e-commerce items than the German auditors. The more granular approach to comparing the two populations seems to provide more detailed comparison, therefore, Construct B breaks out these items into a separate construct labeled as Networking and Data Transfer. Construct C, General Office Automation, has 100\% agreement between the two populations. Construct D, Audit Automation has very similar loading, with agreeance on four important audit technologies. Finally, construct E, Accounting Firm Automation includes two important technologies, but interestingly, time management and billing did not load onto this construct for the German auditors. Thus, interpretation of the factor analysis suggest the following pooled constructs:

1. E-commerce technologies

2. Networking and data transfer

3. General office automation technologies

4. Audit automation technologies, and

5. Accounting firm office automation technologies

\section{Tests of $\mathrm{H} 1$ and $\mathrm{H} 2$}

- H1: The perceived knowledge level (IT self-efficacy) of German and US auditing practitioners includes relevant, current information technologies.

To examine the first hypothesis, a benchmark is needed against which to measure the reported knowledge levels for the set of IT skills. Since we are independently assessing the perceived knowledge levels of the U.S. and German auditors, we use the raw data rather than the culturally adjusted data. We chose the midpoint of the response range as the benchmark. Figure 3 illustrates the distributions of the pooled items within each of the five constructs for the raw data. Those diagram skewed to the left indicate a tendency towards less knowledge (e- 
commerce, networking and data transfer, and audit automation) and those skewed to the right indicate a tendency towards greater knowledge (general office automation and accounting firm automation). Using a seven-point scale, the midpoint is 4 , so we consider the percentage of respondents that are below the midpoint, meaning the percentage of respondents that selected 1,2 , or 3 on a 7point scale with 1 being No Knowledge. If $50 \%$ or more of the respondents are below the mid-point, we conclude that the sample groups were not very knowledgeable for that technology.
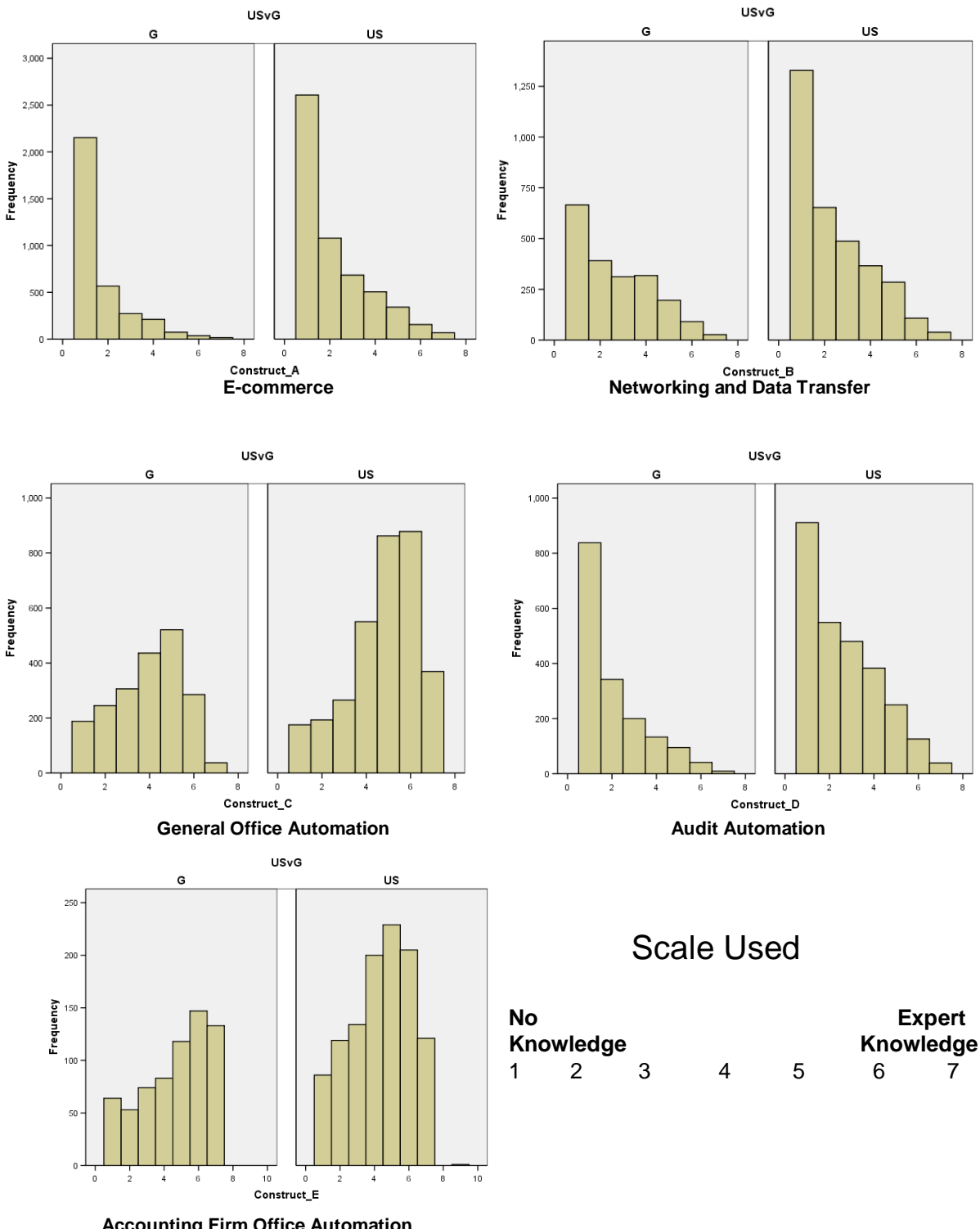

Figure 3. Histograms of Constructs - Raw Data 
The results are also consistent with mean analysis. Chi-squared tests of distributions were conducted on each of the 36 items comparing a 50-50 distribution $(1,2,3$ vs. 5,6,7), and the results are noted in Table 7 .

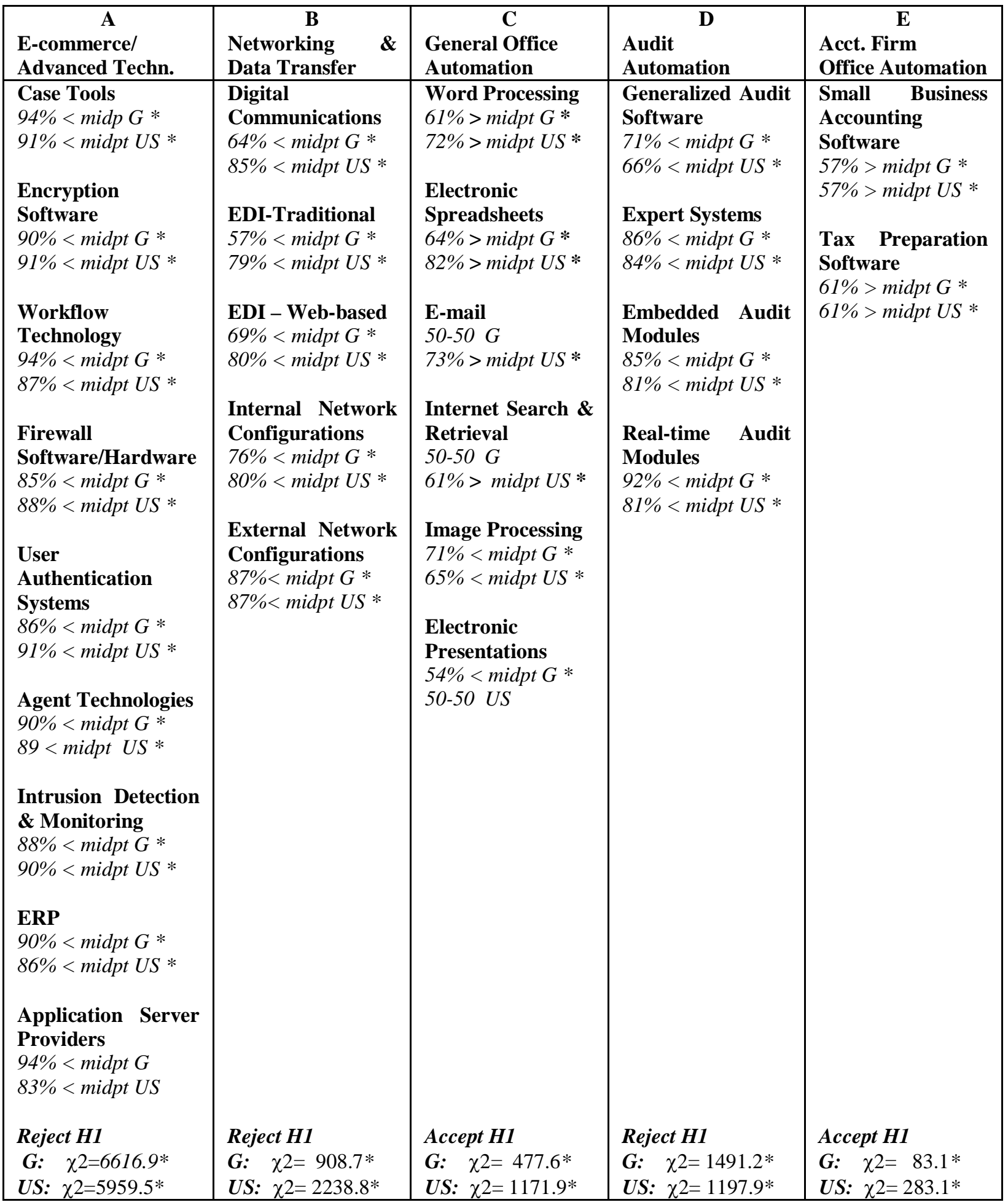


Table 7 indicates a much higher proportion of respondents than $50 \%$ selecting 1,2 , or 3 for the following constructs: e-commerce technologies, networking and data transfer, and audit automation. Extremely high percentages of the respondents rated themselves lower than the mid-point for many of the individual technologies, such as $90-91 \%$ for encryption software, $86-90 \%$ for ERP, $86-91 \%$ for user authentication systems, and $88-90 \%$ for intrusion detection \& monitoring! For the construct accounting firm office automation, both German and US auditors indicate a high degree of knowledge with these items as indicated by the high number of responses above the midpoint (scores of 5, 6, and 7). On the other hand, the evidence was not entirely clear for the general office automation construct. Both German and US auditors seem comfortable with word processing and electronic spreadsheets as evidenced by the high number of responses above the midpoint (scores of 5, 6, and 7). Both groups however, indicated a low knowledge level for image processing and average knowledge level for internet search and retrieval and electronic presentations. Pooled Chi-Squared tests for all of the items in each of the constructs are also conducted and the results are reported in Table 7 and summarized below:

Construct

E-commerce technologies

Networking and Data Transfer

General Office Automation

Audit Automation

Accounting Firm Office Automation
H1

Reject for both G \& US

Reject for both G \& US

Accept H1

Reject for both G \& US

Accept H1

The overall interpretation is that both German and U.S. auditors only have adequate information technology for two of the five constructs. However, an alternative interpretation might be that knowledge of all the individual information technologies is not actually necessary to exercise professional judgment adequately. Many auditors may not perform tasks which require all the specific information technology knowledge surveyed. Also, they might rely on specialists to handle various information technology tasks. 
- H2: German and US auditing practitioners have the same perceived knowledge of relevant, current information technologies (IT self-efficacy).

In the test of $\mathrm{H} 2$, the relative skill sets of the two groups are examined. Since the two groups are being compared against one another, the cultural adjustment is made. However, both the raw data and culturally adjusted data are analyzed and tested to see how robust the results are across the two data sets. Overall, the results were identical for 21 out of 36 (58\%) technologies. For these 21 technologies, 18 were statistically significantly different between the two countries. For the remaining 15 items, the cultural adjustments affected the results significantly. In approximately one-half of the cases (8), the statistical significance increased from insignificant to significant because of the cultural adjustments. The remaining cases either decreased in significance ( 5 cases) because of the cultural adjustment or actually switched directions ( 2 cases). Thus, the cultural adjustment does indeed affect the significance at the individual item level.

\section{Item Information Technology}

1 Word Processing

2 Electronic Spreadsheets

3 E-Mail

4 Electronic Working Papers

5 Internet Search \& Retrieval

6 Image Processing

7 Electronic Presentations

8 Generalized Audit Software

9 Expert Systems

10 Embedded Audit Modules

11 Real-time Audit Modules

12 Database Search \& Retrieval

13 Simulation Software

14 Flowcharting/Data Modeling

15 CASE Tools

16 Encryption Software

17 Groupware

18 Cooperative Client/Server Env.

\section{Culturally \\ Adjusted \\ Data \\ Raw Data \\ 05 or better \\ Consistent \\ Type of \\ Change}

US $>\mathrm{G}$ No difference

US $>\mathrm{G}$ No difference

US $>\mathrm{G} \quad$ US $>\mathrm{G} \quad$ Yes

US $>\mathrm{G} \quad$ US $>\mathrm{G} \quad$ Yes

US $>\mathrm{G} \quad \mathrm{US}>\mathrm{G} \quad$ Yes

No difference No difference Yes

No difference No difference Yes

No difference No difference Yes

No difference $\quad U S>G$

No difference

$\mathrm{US}>\mathrm{G}$

$\mathrm{US}>\mathrm{G}$

$\mathrm{US}>\mathrm{G}$

US $>\mathrm{G}$ No difference

US $>\mathrm{G} \quad \mathrm{US}>\mathrm{G}$

US $>\mathrm{G}$

$\mathrm{US}>\mathrm{G}$

No difference

$\mathrm{US}>\mathrm{G}$

$\mathrm{US}>\mathrm{G}$
$\mathrm{US}>\mathrm{G}$

$\mathrm{US}>\mathrm{G}$

$\mathrm{US}>\mathrm{G}$

$\mathrm{US}>\mathrm{G}$

US $>\mathrm{G}$ Yes

Yes -significance

-significance

+ significance

+ significance

Yes

-significance

Yes

Yes

Yes

+significance 


\begin{tabular}{|c|c|c|c|c|c|}
\hline 9 & Workflow Technology & $\mathrm{US}>\mathrm{G}$ & $\mathrm{US}>\mathrm{G}$ & Yes & \multirow{5}{*}{-significance } \\
\hline 20 & Database Design \& Installation & $\mathrm{US}>\mathrm{G}$ & $\mathrm{US}>\mathrm{G}$ & Yes & \\
\hline & Time Management \& Billing & \multirow{2}{*}{\multicolumn{2}{|c|}{ US $>$ G No difference }} & & \\
\hline & Systems & & & \multirow[b]{2}{*}{ Yes } & \\
\hline & Test Data & $\mathrm{US}>\mathrm{G}$ & $\mathrm{US}>\mathrm{G}$ & & \\
\hline & Small Business Accounting Software & No difference & $\mathrm{G}>\mathrm{US}$ & & + significance \\
\hline & Digital Communications & $\mathrm{G}>\mathrm{US}$ & $\mathrm{G}>\mathrm{US}$ & Yes & \\
\hline & Tax Return Preparation Software & No difference & $\mathrm{G}>\mathrm{US}$ & & +significance \\
\hline & Firewall Software/Hardware & No difference & $\mathrm{US}>\mathrm{G}$ & & +significance \\
\hline & User Authentication Systems & $\mathrm{G}>\mathrm{US}$ & $\mathrm{US}>\mathrm{G}$ & & Directional \\
\hline & EDI-Traditional & $\mathrm{G}>\mathrm{US}$ & $\mathrm{G}>\mathrm{US}$ & Yes & \\
\hline & EDI-Web Based & $\mathrm{G}>\mathrm{US}$ & $\mathrm{G}>\mathrm{US}$ & Yes & \\
\hline 0 & Wireless Communications & $\mathrm{G}>\mathrm{US}$ & $\mathrm{G}>\mathrm{US}$ & Yes & \\
\hline 31 & Agent Technologies & No difference & $\mathrm{US}>\mathrm{G}$ & & +significance \\
\hline 32 & Intrusion Detection \& Monitoring & $\mathrm{G}>\mathrm{US}$ & $\mathrm{US}>\mathrm{G}$ & & directional \\
\hline 3 & Internal Network Configurations & $\mathrm{G}>\mathrm{US}$ & ference & & -significance \\
\hline & External Network Configurations & No difference & $\mathrm{US}>\mathrm{G}$ & & + significance \\
\hline & Enterprise Resource Planning & $\mathrm{US}>\mathrm{G}$ & $\mathrm{US}>\mathrm{G}$ & Yes & \\
\hline & Application Service Providers & $\mathrm{US}>\mathrm{G}$ & $\mathrm{US}>\mathrm{G}$ & Yes & \\
\hline
\end{tabular}

Table 8. Mann-Whitney U-test Results Comparison Raw Data vs. Culturally Adjusted Data

In testing $\mathrm{H} 2$, we need to consider the significance and direction of any differences between the U.S. and German auditors for the pooled items under each construct. We also need to be cognizant of the impact on the results due to the cultural adjustment. Table 9 demonstrates the statistical significance of each of the individual items using Mann-Whitney test results for both the raw data and culturally adjusted data. Symbols are used to denote for each item the consistency between raw and adjusted data. Also, the items in each of the constructs are pooled and an F-test is used to determine the significant differences between the U.S. and German auditors. The construct level (pooled items) tests are run on both the raw data (RD) and the culturally adjusted data (CAD), and the results are completely consistent for four of the five constructs as reported in Table 9. The following results are found and also reported in Table 9:

Construct

E-commerce technologies

Networking \& Data Transfer
$\mathrm{H} 2$

Reject $\mathrm{H} 2$

Reject $\mathrm{H} 2$ 
General Office Automation

Audit Automation

Accounting Firm Office Automation
Reject H2

Reject H2

Accept $\mathrm{H} 2$

\begin{tabular}{|c|c|c|c|c|}
\hline $\begin{array}{r}\text { A } \\
\text { E-commerce }\end{array}$ & \begin{tabular}{ll}
\multicolumn{1}{c}{ B } & \\
Networking & $\&$ \\
Data Transfer &
\end{tabular} & \begin{tabular}{l}
\multicolumn{1}{c}{ C } \\
General Office \\
Automation
\end{tabular} & \begin{tabular}{l}
\multicolumn{1}{c}{ D } \\
Audit \\
Automation
\end{tabular} & \begin{tabular}{l}
\multicolumn{1}{c}{$\mathbf{E}$} \\
Accounting Firm \\
Office \\
Automation
\end{tabular} \\
\hline $\begin{array}{l}\text { CASE Tools } \\
\text { US }>\text { G } \$ \\
\text { Encryption Software } \\
\text { US }>\text { G + } \\
\text { Workflow } \\
\text { Technology } \\
\text { US }>\text { G } \$ \\
\text { Firewall } \\
\text { Software/Hardware } \\
\text { US }>\text { G + } \\
\text { User Authentication } \\
\text { Systems } \\
\text { Direction unclear } \\
\text { Agent Technologies } \\
\text { US }>\text { G + } \\
\text { Intrusion Detection } \\
\text { \& Monitoring } \\
\text { US }>\text { G } \\
\text { Direction unclear } \\
\text { ERP } \\
\text { US }>\text { G }+ \\
\text { Application Server } \\
\text { Providers } \\
\text { US }>\text { G }+\end{array}$ & $\begin{array}{l}\text { Digital } \\
\text { Communications } \\
\text { G>US }+ \\
\text { EDI-Traditional } \\
\text { G>US } \div \\
\text { EDI - Web-based } \\
\text { G>US }+ \\
\text { Internal Network } \\
\text { Configurations } \\
\text { G>US - } \\
\text { External Network } \\
\text { Configurations } \\
\text { US }>\text { G + }\end{array}$ & $\begin{array}{l}\text { Word Processing } \\
\text { G>US - } \\
\text { Electronic } \\
\text { Spreadsheets } \\
\text { US }>\text { G - } \\
\text { E-mail } \\
\text { US }>\text { G }+ \\
\text { Internet Search \& } \\
\text { Retrieval } \\
\text { US>G } \$ \\
\text { Image Processing } \\
\text { No difference } \$ \\
\text { Electronic } \\
\text { Presentations } \\
\text { no difference } \$\end{array}$ & $\begin{array}{l}\text { Generalized } \\
\text { Audit Software } \\
\text { No difference }+ \\
\text { Expert Systems } \\
\text { US }>\text { G + } \\
\text { Embedded } \\
\text { Audit Modules } \\
\text { US }>\text { G + } \\
\text { Real-time Audit } \\
\text { Modules } \\
\text { US }>\text { G }+\end{array}$ & $\begin{array}{l}\text { Small Business } \\
\text { Accounting } \\
\text { Software } \\
\text { G>US + } \\
\text { Tax Preparation } \\
\text { Software } \\
\text { G>US + }\end{array}$ \\
\hline $\begin{array}{l}\text { Reject } \mathrm{H} 2 \\
\text { CAD: } \quad \mathbf{F}=12.8^{*} \\
\text { RD: } \quad \mathbf{F}=12.9 *\end{array}$ & $\begin{array}{l}\text { Reject H2 } \\
\text { CAD: } \quad \mathrm{F}=\mathbf{2 4 . 2} * \\
\text { RD: } \quad \mathrm{F}=\mathbf{2 0 . 6} *\end{array}$ & $\begin{array}{l}\text { Reject } \mathbf{H} 2 \\
\text { CAD: } \quad F=10.3 * \\
\text { RD: } \quad F=20.5 *\end{array}$ & $\begin{array}{l}\text { Reject } \mathbf{H 2} \\
\text { CAD: } \quad \mathbf{F}=7.7^{*} \\
\text { RD: } \quad \mathbf{F}=8.1^{*}\end{array}$ & $\begin{array}{l}\text { Accept H2 } \\
\text { CAD: } \quad F=4.7^{*} \\
\text { RD: } \quad F=1.1\end{array}$ \\
\hline
\end{tabular}

Table 9 - Tests of $\mathrm{H} 2$

Pooled Constructs: Raw Data (RD) and Culturally Adjusted Data(CAD) F-tests

$\ddagger$ denotes consistent Mann-Whitney test results of $\mathrm{RD}$ and $\mathrm{CAD},+$ denotes increased significance using

$\mathrm{CAD}$; - denotes decreased significance using CAD,

*two-tailed tests significant at.01 or better 
The F-test results of pooled items for each of the constructs were statistically significant at .0001 or better for the both raw data and culturally adjusted data. The results indicate that for three of the constructs, e-commerce, networking and data transfer, and audit automation, U.S. practitioners have a statistically significant greater perceived knowledge level (IT self-efficacy) than the German practitioners. For one of the constructs, networking and data transfer, the German practitioners have a statistically significant greater perceived knowledge (IT self-efficacy) level than the U.S. practitioners. The F-test results were not robust across the raw data and culturally adjusted data for only one of the constructs, accounting firm office automation. For this construct, significant differences were found for the culturally adjusted data, but not the raw data. Because of these inconsistencies and the controversy surrounding the appropriateness of culturally adjusted data, we do not reject $\mathrm{H} 2$ for this construct.

\section{Discussion of Results}

When we consider the results of the testing of the two hypotheses, we get a more holistic view of similarities and differences in US and German auditors:

\begin{tabular}{|c|c|c|c|c|}
\hline Factor 1 & Factor 2 & Factor 3 & Factor 4 & Factor 5 \\
\hline E-commerce & Networking \& & General Office & Audit & Accounting Firm \\
\hline Technologies & Data Transfer & Automation & Automation & $\begin{array}{l}\text { Office } \\
\text { Automation }\end{array}$ \\
\hline Reject H1 & Reject H1 & Accept H1 & Reject H1 & Accept H1 \\
\hline Reject $\mathrm{H} 2$ & Reject H2 & Reject H2 & Reject H2 & Accept H2 \\
\hline $\begin{array}{l}\text { US auditors } \\
\text { report greater } \\
\text { knowledge } \\
\text { level than G } \\
\text { auditors }\end{array}$ & $\begin{array}{l}\text { German auditors } \\
\text { reporter greater } \\
\text { knowledge level } \\
\text { than US Auditors }\end{array}$ & $\begin{array}{l}\text { US auditors report } \\
\text { greater knowledge } \\
\text { level than G } \\
\text { auditors }\end{array}$ & $\begin{array}{l}\text { US auditors report } \\
\text { greater knowledge } \\
\text { level than G } \\
\text { auditors }\end{array}$ & \\
\hline
\end{tabular}

On a seven-point scale with 7 being Expert Knowledge and 1 being No Knowledge, the overall means of the 36 non-culturally adjusted information technology knowledge (IT self-efficacy) for the US audit practitioner and German audit practitioners were very low at 2.79 and 2.61 , respectively. The mean reported skill levels on three of the constructs are disturbingly low in both countries as 
indicated visually in Figure 3 and by the Chi-Square tests of distributions reported in Table 7. Specifically, we found that the skill sets of German and US audit practitioners were on the low side of a seven point scale, the mode was 1-No Knowledge, for three constructs: e-commerce technologies, networking and data transfer, and audit automation. We did find some good news, however, the skill sets for both groups are perceived as being on the high side for two constructs: general office automation and accounting firm office automation. These technologies are not really considered emerging technologies, so finding moderate to high knowledge levels on these two constructs is both comforting and provides logical validity to the overall results.

The other three constructs, however, are the more emerging technologies. Bierstaker, et al (2003) found that the percentage of internal auditors surveyed in 2002 that used various software was quite low, thus indicating that these technologies are still very much emerging, both in design and in use. For example, for e-commerce privacy and integrity, only $12 \%$ of the internal auditors used software, for specialized fraud, only 19\% used software, and for continuous transaction monitoring, only $18 \%$ used software. For organizations with revenues less than $\$ 250 \mathrm{M}$, no internal auditors surveyed used any of these types of software. The major reasons cited for not using such software was not cost, but that the software was not available. Cost was the second reason, however, thus indicating that if software is available, they either are not aware of it, do not fully understand the benefits from a cost-benefit perspective, or the newness of the software simply has too high of a price-tag that can only be afforded by larger organizations.

When the US and German auditor practitioners are examined in comparison with one another, both before and after making a cultural adjustment to the data, statistically significant differences are found between the two groups for four of the constructs: e-commerce, networking and data transfer, general office automation, and, audit automation.

For the construct e-commerce technologies, both German and US practitioners have very low perceived knowledge levels, and overall the US auditors tend to have higher skill levels. For the construct networking and data transfer, EDI (traditional and web-based), digital communications, and Internal Network Configurations, the German audit practitioners have higher perceived knowledge levels (IT self-efficacy) than their US counterparts. The historically greater 
wireless movement in Europe may explain their enhanced comfort level with wireless and network communications.

For the construct audit automation, both groups of practitioners have low perceived knowledge levels on all items. For three out of four items in this construct, the German audit practitioners had statistically significant lower self perceived knowledge than the US audit practitioners. One potential explanation for this finding could be that German auditors perform less tests of controls (and more test of details) than US auditors. Also, it may be due to a lower average size of client base in Germany. The only item for which no differences are found between the US and German auditors is generalized audit software.

Some good news from this study is that, overall, both US and German audit practitioners appear to be comfortable with general office automation. Both German and US practitioners have a medium to relatively high level of perceived knowledge on four of the six items in this construct: word processing, electronic spreadsheets, e-mail, and internet search and retrieval. While overall, the two groups are relatively comfortable with the technologies in this category, they are substantially less comfortable with image processing and electronic presentations than with the other four items in this construct. Overall, US auditors are slightly more comfortable with this construct than the German auditors, although not necessarily on all individual items.

For the construct accounting firm office automation, the results are not that different: both German and US audit practitioners have a relatively high level of perceived knowledge, which is more good news. This is not surprising because these types of technologies are those which many auditing practitioners are exposed to frequently. The US auditors, however, did report a statistically significant lower level of knowledge on this construct than did the German auditors using the culturally adjusted data, but not the raw data. Put another way, both US and German auditors are comfortable with accounting firm office automation, but the Germans may be more comfortable than their US counterparts. In Germany, relatively more sole practitioners and small audit firms exist, and bookkeeping and tax consulting services are much more important than audit services. Further, German tax laws are considered to be among the most complex in the world and even more complex than U.S. tax laws. This may account for the culturally 
adjusted results indicating that the German auditors are more knowledgeable that US auditors regarding tax return preparation software.

\section{Research Limitations}

All survey research has a number of limitations which may affect the usefulness and validity of the results. Some were acknowledged previously while others are discussed below. A general limitation of this type of research is that since the questionnaire asked the respondents to rank their own knowledge there is no way to determine if their rankings are an accurate depiction of actual knowledge. Kennedy and Peecher (1997) find that auditors are overconfident in their technical knowledge when performing self-assessments. Their study examined their self-perceived vs. actual knowledge of GAAP and GAAS, so their results may not be generalizable to the IT domain. However, if auditors are similarly overconfident in their assessment of their IT knowledge, then the need for increased professional development in this area is even greater.

Another limitation, as previously acknowledged, is that many of the technologies overlap conceptually. We were not able to find a technology taxonomy which would enable us to select conceptually distinct information technologies with which audit practitioners would be readily familiar. We attempted to overcome this limitation by conducting factor analysis and systematically identifying constructs and by examining aggregated items by construct.

Some IT knowledge may be more related to efficiency issues rather than effectiveness. Accordingly, lack of knowledge in some IT areas may not be as significant in terms of society relying on auditor work. One further limitation is that the 36 information technologies examined in this research were subjectively selected by the researchers from English literature. Equally significant technologies may not have been identified or selected. Additional technologies were not sought from the German literature.

We were only able to incorporate limited checking for non-respondent bias. This consisted principally of comparing sample means of early respondents to late respondents for significant differences, and no overall significant differences were found. The possibility exists that individuals who did not respond to this survey may have different information technology knowledge levels. Further, for the 
German sample, the "Big 5" was basically represented by one "Big 5" firm and not all five firms. The results from this one firm may not be generalizeable to the other "Big 5" audit firms.

A final factor to consider is that the U.S. survey was English language based while the German survey was German language based. Although, careful translations were made and verified by other individuals, language differences could have affected the survey results. In some cases for the German survey English expressions were used since there was no apparent clear German equivalent.

\section{CONCLUSIONS}

As widely acknowledged in the literature, appropriate knowledge of information technology is critical for the auditing profession. This research measured IT knowledge for U.S. and German audit professionals via national surveys in each country. A principal finding is that a statistically significantly different knowledge level (IT self-efficacy) is found between the two countries for four of the five constructs identified in the factor analysis using both the raw data and culturally adjusted data: e-commerce technologies, networking and data transfer, general office automation, and audit automation. This raises the question of whether this difference was created by the educational system, firm training, or continuing professional education.

Another important finding was that more than $25 \%$ of the auditing profession in both countries self-rated their IT knowledge as "Less Than Adequate." This does not sound like the surveyed professionals believe they are meeting the "advanced level" of IT knowledge suggested by IFAC, and this suggests that the auditing professions in both countries need to address this issue if the profession is to appropriately meet the needs of society. Calibrating self-assessments of IT knowledge is important, and measuring auditors' knowledge levels of relevant IT knowledge is critical to the audit profession. Continuous improvement is unlikely if auditors are overconfident about their IT skill levels. Further, absent feedback about their true "IT" skill levels, auditors will be unlikely to question, and certainly not improve their knowledge (Arkes et al. 1987). Further, the resources used to enhance auditors' IT skills "needs to be considered an 'investment' rather than a 'cost"' (Nance and Straub, 1996). 
Another consideration in interpreting the results should be that knowledge of all 36 information technologies may not be necessary for many professionals to meet their responsibilities adequately. Many audit practitioners work in areas where some of the technologies may not be necessary or useful. Some of the information technologies may be necessary only for specific tasks. Selecting a "low tech" approach when IT is not useful can lead to improved performance, while "using technology that is not useful for the task may have minimal or even dysfunctional performance effects" (Nance and Straub 1996). However, Bedard et al. (2006) find that reviewers (managers) are less influenced by the ease of use (which is impacted by computer self-efficacy) of a system than are the preparers. They pose that the "greater importance of system efficiency among audit managers and partners is likely related to their accountability as senior officers." Thus, emerging technologies by definition will have lower IT self-efficacy, (a concept supported by this study), and in order to increase adoption, the usefulness and efficiency of the system needs to be made clear to senior managers to increase their adoption. One objective of this study was to initiate discussion, debate, and action that will lead to positive changes in the international auditing profession. We believe the information obtained provides a basis for moving in that direction.

Future researchers may wish to further investigate why the self-reported IT knowledge levels of certain technologies, such as test data, in Figure 2, load differently onto different constructs in different countries. Also, future researchers can measure whether, as an "emerging technology" matures, greater convergence will occur over time in factor analysis, as in the case of the more mature construct, General Office Automation (100\% convergence) in Figure 2. Finally, this study provides a great basis and benchmark for other researchers to continue to study the IT skill levels of auditors worldwide. The required IT skills may change over time, and the systematic study and documentation of such changes across cultures is worthwhile. Comparing the composition of constructs over time and how different cultures "emerge" in their understanding of the underlying technologies could perhaps even help to predict, in the future, which "culture" or population may be best poised for the next generation of technological change. 


\section{REFERENCES}

AICPA (2000): AICPA Top Ten Technologies. American Institute of Certified Public Accountants. New Jersey. Available at http://www.aicpa.org/infotech/technologies /toptechs/2000.htm.

AICPA (1997): AICPA Top Ten Technologies. American Institute of Certified Public Accountants. New Jersey. Available at http://www.aicpa.org/infotech/technologies /toptechs/1997.htm.

AICPA (1994): Auditing with Computers. Auditing Procedures Study. American Institute of Certified Public Accountants. New York, NY.

ANONYMOUS (2003): "Special Report: The new geography of the IT industry Information technology", The Economist, vol. 368 (8): 333- 353

ARKES, H.; CHRISTENSEN, C.; LAI, C.; BLUMER, C. (1987): "Two Methods of Reducing Overconfidence", Organizational Behavior and Human Decision Processes (February), vol. 39 (1): 133-144.

BEDARD, J.; ETTREDGE, M.; JOHNSON, C.; JOHNSTONE, K. (2006): "Knowledge, Experience and Work-Around Behaviors: Electronic Media in the Professional Audit Environment," Working Paper.

BIERTAKER, J.; BURNABY, P.; HASS, S. (2003): "Recent Changes in Internal Auditors' Use of Technology”, Internal Auditing, vol. 18 (4): 39-45.

BIERSTAKER, J.; BURNABY, P.; THIBODEAU, J. (2001): "The Impact of Information Technology on the Audit Process: An Assessment of the State of the Art and Implications for the Future," Managerial Auditing Journal, vol. 16 (2): 159-164.

CHANG, C. J.; HWANG, N. R. (2003): “Accounting Education, Firm Training and Information Technology: A Research Note", Accounting Education, vol. 12: 441-450.

DAVIS, F. (1989): "Perceived Usefulness, Perceived Ease of Use, and User Acceptance of Information Technology," MIS Quarterly, vol. 3 (3): 319-340.

DE ANGELO, L. (1981): “Auditor Size and Audit Quality,” Journal of Accounting \& Economics, vol. 3 (3): 183-200. 
ELLIOT, R. K. (1994): "Confronting the Future: Choices for the Attest Function." Accounting Horizons, vol. 8 (3): 112-114.

FISCHER, R. (2004): "Standardization to Account for Cross-Cultural Response Bias: A Classification of Score Adjustment Procedures and Review of Research in 'JCCP'”, Journal of Cross-Cultural Psychology, vol. 35 (3): 263-282.

GLOVER, S. M.; ROMNEY, M. (1997): "20 Hot Trends-The Software Revolution is Fueling Change and Challenge in Internal Auditing", Internal Auditor, vol. 54 (4): $28-38$.

GREENSTEIN, M.; FEINMAN, T. (2001): Electronic Commerce: Security, Risk Management, and Control. Irwin-McGraw Hill, New York, NY.

GREENSTEIN, M.; MCKEE, T. E. (2004): “Assurance Practitioners' and Educators' Self-Perceived IT Knowledge Level: An Empirical Assessment", International Journal of Accounting Information Systems, vol. 5 (2): 213-243.

HELMS, G.L.; MANCINO, J. (1998): "The Electronic Auditor-Wave Goodbye to the Paper Trail”, Journal of Accountancy, vol. 185 (4): 45-48.

IFAC, EDUCATION COMMITTEE (2003): International Education Guideline 11: Information Technology for Professional Accountants. International Federation of Accountants (IFAC), Education Committee.

IFAC, IAESB (2006a): International Education Standard 8: Competence Requirements for Audit Professionals. International Federation of Accountants (IFAC), International Accounting Education Standards Board (IAESB).

IFAC, IAESB (2006b): International Education Practice Statement (IEPS) 2.1, Information Technology for Professional Accountants. International Federation of Accountants (IFAC), International Accounting Education Standards Board (IAESB).

JANVRIN, D.; BIERSTAKER, J.; LOWE, D.J. (2008). “An Examination of Audit Information Technology Use and Perceived Importance", Accounting Horizons, vol. 22 (1): 1-21.

KENNEDY, J.; PEECHER, M. E. (1997): “Judging Auditors' Technical Knowledge”, Journal of Accounting Research, vol. 35 (2): 279-293. 
KEREN, G. (1991): "Calibration and Probability Judgments: Conceptual and Methodological Issues”, Acta Psychologica, October : 217-273.

LEUNG, K.; BOND, M. H. (1989): "On the Empirical Identification of Dimensions for Cross-Cultural Comparisons", Journal of Cross-Cultural Psychology, vol. 20: 133-151.

LYMER, A.; DEBRECENY, R. (2003): "The Auditor and Corporate Reporting on the Internet : Challenges and Institutional Responses", International Journal of Auditing, vol. 7: 103-120.

MCKEE, T. E. (2000): Accounting/Auditing Technology in Norway: An Investigation of the Norwegian Accounting/Auditing Professions Knowledge and Views on Information Technologies. Norwegian Institute of Public Accountants (DnR), Oslo, Norway.

MCKEE, T.E.; QUICK, R. (2003): "IT-Kenntnisse der wirtschaftsprüfenden Berufsstände-eine Empirische Untersuchung" (Information Technology-Knowledge in the Auditing Profession-An Empirical Study), Die Wirtschaftsprüfung, vol. 56 (10): 541-547.

MOECKEL, C. (1990): "The Effect of Experience on Auditors' Memory Errors". Journal of Accounting Research, vol. 28 (2): 368-387.

MOECKEL, C.; PLUMLEE, R. (1989): “Auditors' Confidence in Recognition of Audit Evidence", The Acounting Review, vol. 64 (4): 653-666.

NANCE, W.; STRAUB, D. (1996): “An Investigation of Task/Technology Fit and Information Technology Choices in Knowledge Work", Journal of Information Technology Management, vol 7 (3, 4): 1-14.

SMITH, P.B. (2004): "Acquiescent Response Bias as an Aspect of Cultural Communication Style", Journal of Cross-Cultural Psychology, vol. 35: 50-61.

SMITH, P. B.; PETERSON, M. F.; SCHWARTZ, S. H., et al. (2002): "Cultural Values, Sources of Guidance, and their Relevance to Managerial Behavior - a 47 Nation Study", Journal of Cross-Cultural Psychology, vol. 33 (2): 188-208.

SOLOMON, I..; ARIYO, A.; TOMASSINI, L. (1985): "Contextual Effects of the Calibration of Probabilistic Judgments", Journal of Applied Psychology, vol. 70 (3): 528-552. 
YU, J. (2002): “An Accountant's Top 10 IT Review”, CGA Magazine, SeptemberOctober. Available at http://www.cga-canada.org/eng/magazine/sep-oct02/TopTen_e.htm. 